\title{
Examination of Some Physical Fitness and Motor Skill Parameters of Pre-Adolescents and Adolescents
}

\author{
Fatma Arslan \\ Correspondence: Fatma Arslan, Necnettin Erbakan University, Faculty of Tourism, Department of Recreation \\ Management, Konya, Turkey
}

Received: June 29, 2018

Accepted: July 17, 2018

Online Published: July 19, 2018

doi:10.11114/jets.v6i9.3396

URL: https://doi.org/10.11114/jets.v6i9.3396

\begin{abstract}
The aim of this study was to analyze the importance of some physical fitness and motor skills for children between 11-13 years at elementary school. A total of 114 primary school children participated as volunteers with a means age of $10.80 \pm 0,40$ for $5^{\text {th }}$ grade and $12.83 \pm 0,38$ for $7^{\text {th }}$ grade.

In this study, some motor tests were used to detect differences between pre-adolescence and adolescence on male and female. These tests were respectively: for dynamic balance "The Star excursion balance test", for the agility "T-test", "V sit and reach" for flexibility test and for explosive strength a "20 m run $(0.1 \mathrm{~s})$ ". Besides, physical fitness features were taken as height, weight, body mass index (BMI) and waist-hip ratio (WHR).

The results of the flexibility showed that the female children had better performances in the $5^{\text {th }}$ grade than those in the $7^{\text {th }}$ grade children $(p<0,005)$. In addition, it was determined that the dynamic balance performance values of the $7^{\text {th }}$ grade female and male children were better than the $5^{\text {th }}$ grade $(\mathrm{p}<0,005)$. There were significant differences in agility and explosive strength between the $7^{\text {th }}$ grade female and male children $(\mathrm{p}<0,005)$.

It was observed that there was an increase in agility, speed and dynamic equilibrium performance data especially from the age of 11 in parallel with growth and development. Especially from this period, it was thought that it was possible to develop motor skills and performance parameters with some sports applications and training.
\end{abstract}

Keywords: gender, children, adolescent, motor skill

\section{Introduction}

Naturally, people have to act constantly whyever survive in difficult living conditions (Zorba, 2001). While investigating the motor behavior, a progressive viewpoint is needed to understand movement and mobility(Clark,2005). Henderson and Sugden reported that motor ability can be defined as the ability of a person to carry out different motor actions, including coordination of both good and large motor skills. In the development of motor skills are mostly taken into account the level of competence/competence in mobility skills(Henderson \& Sugden, 1992). It has been reported that a profound motor competence level is necessary for strong general development, as well as for health, psychosocial development, and well-being (Haga, 2008; Piek et al., 2006). Motor skills are positively associated with both physical fitness and physical activity (Hands et al. 2009). Physical fitness includes cardiovascular endurance, muscle strength, speed, flexibility, agility, balance, reaction time and body composition(Özer, 2006).

Flexibility is defined as the ability of people to perform their actions within a large range of angular value (Bompa, 2003). Flexibility is influenced by anatomical and physiological changes that occur in the adolescent period. Flexibility is stable in men between the ages of 5 and 8 . When it reaches 12-13 years, it decreases. It stays constant between 13-15 years and then increases again until 18 years old(William et al.,1989). Besides, Flexibility is effective in ensuring an optimal development that is suited to the needs of the sports branch from physical factors such as the strength, speed, and development of technique (Kocak et al., 2005). Speed is the ability of the human musculoskeletal system to support linear body displacement until it reaches maximum velocity(Ross et al., 2001). It has been reported that age positively affects sprint speed; and boys of all ages ran faster than girls, especially after childhood(Branda et al., 1984). The first stage of sprint performance begins to develop in children at the age of 8 years; The second phase starts in girls 12 years and in males 12-15 years(Reilly et al. 2000).

Locomotor (eg, agility) and stability (eg, dynamic balance) are essential and necessary skills for physical activity and sports 
participation at all ages(Fong \& Ng, 2012; Gallahue, Ozmun, \& Goodway, 2012; Jordan, et al. 2014; Santiago, et al. 2015). The agility improves naturally throughout childhood and adolescence. However, the onset of the pubertal, it is evident that sex-associated differences begin to appear, the development of change of direction speed performance occurs at approximately 13-14 years of age in male youths which is commensurate with the timing of peak height velocity(Vanttinen et al.,2011). Miller et al. (2006) said that The relationship between agility and balance is assumed and, balance and coordination improvements might provide faster movements and faster direction changes while maintaining control. While the agility is defined as a body movement with changes in speed or direction in response to a stimulus by Sheppard \& Young, (2006); Ruiz et al. (2009) reported that balance is considered as an agility subcomponent. It is mentioned that dynamic balance is an important skill in all age groups and is necessary for regular daily activities such as walking, running or other physical activities requiring control of dynamic movements(Gallahue \& Ozmun,2006). In addition, it is mentioned that motor health including balance and coordination is part of physical well-being in childhood and adulthood. Balance is one of the basic mobility skills for physical development, showing functional participation in activities and gaining motor skills(Stepinski et al. 2003; Westcott et al., 1997). In this study, the purpose was to determine some health-related physical fitness and motor skill parameters of pre-adolescents and adolescents. In addition, It also aimed to examine the development and differences of some components of motor skill competence (eg, dynamic balance, flexibility, speed and agility) and health-related physical fitness (eg Weight, BMI, WHR) according to age, grade and gender.

\section{Method}

\subsection{The Model of the Study}

This study was conducted to analyze the importance of some physical fitness and motor skills for $5^{\text {th }}$ and $7^{\text {th }}$ grade children by gender. A causal-comparison model from quantitative research methods was used in the study. The measurements were taken once and all measurements were saved immediately.

\subsection{Population and Sample}

The study included 114 children of the fifth and seventh-grade elementary school children of which there were 60 male and 54 female. The average age of the children were respectively: $10.80 \pm 0.40$ for $5^{\text {th }}$ grade and $12.83 \pm 0,38$ for $7^{\text {th }}$ grade. The sample of the study was made up of the children who did not have experience in sports previously and participated in the summer sports school for the first time. The school authorities and parents were informed about the purpose and content of the study and consent form was obtained from a parental and school authorities. In addition, their written consent was obtained in accordance with the Child Protection and Rights Convention.

\subsection{Data Collection Tools}

\subsubsection{Height and Body Weight Measurement:}

Height was measured to the nearest $0.1 \mathrm{~cm}$ on a stadiometer when the children were shoeless. Body weight was measured to the nearest $0.1 \mathrm{~kg}$ using a pre-calibrated Tanita instrument (model TBF-305; Tanita, Arlington Heights, IL) electronic scale. BMI was calculated as weight in kilograms divided by height squared $(\mathrm{kg} / \mathrm{m} 2)$ in meters.

\subsubsection{Agility T-Test}

Four cones was set as illustrated in the diagram below ( 5 yards $=4.57 \mathrm{~m}, 10$ yards $=9.14 \mathrm{~m})$. The subjects start at cone A. On the command of the timer, the subjects sprint to cone B and touch the base of the cone with their right hand. Then, they turn left and shuffle sideways to cone $\mathrm{C}$, and also touch its base, this time with their left hand. Then, shuffling sideways to the right to cone $\mathrm{D}$ and touching the base with the right hand. They shuffle back to cone $\mathrm{B}$ touching with the left hand and run backward to cone A. The stopwatch is stopped as they pass cone A(Pauole et al., 2000).

\subsection{3 $20 \mathrm{~m}$ Sprint Test}

The aim of this test was to determine acceleration. The 20-meter runway was marked with a cone on the surface of the hall. The test involved running a single maximum sprint over 20 meters, with the time recorded. A thorough warm up should be given, including some practice starts and accelerations. Subjects start from a stationary position, with one foot in front of the other. The front foot must be on or behind the starting line. Two trials were allowed, and the best time was recorded.

\subsubsection{V-Sit Reach Test}

A straight $30 \mathrm{~cm}$ long line was marked as the starting line for the test to be applied. The measurement line was placed which was $0.1 \mathrm{~mm}$ accuracy and $60-80 \mathrm{~cm}$ in length and perpendicular to the starting line and was $30-40 \mathrm{~cm}$ on either side. The point at which the start and measurement line intersected was accepted as the " 0 " point. The children were asked to remove their shoes and they were told to put their heels $30 \mathrm{~cm}$ apart, just to the sides of the starting line. The children were allowed to sit in their V-shaped legs. The children were asked to put their hands on the palm-rest measuring line and slowly reach forward as far as possible while hands travel along the measurement line. They were 
allowed to do it three times again and the scores were evaluated as negative (-) for the legs behind the starting line plus (+) for the starting line, and the last point reached was recorded(Heyward,2006; Hui\&Yuen 2000).

\subsubsection{Star Excursion Balance Test (SEBT)}

The SEBT is a functional test that occurs on one leg with a maximum reach of the opposite leg. A $2 \mathrm{~m} \mathrm{long,} 7.5 \mathrm{~cm}$ wide adhesive tape was connected to the floor to eight different directions for the test. Every $\mathrm{cm}$ was written on tape to easily measure how far the subject reached. While they were standing on one leg; Children were asked to reach 8 directions (anterior-A, anterolateral-AL, anteromedial-AM, medial-M, posteromedial-PM, posterior-P, posterolateral-PL and lateral-L) and performed the SEBT test. The children were allowed to practice for about a minute (Kinzey\&Armstrong 1998). The test was initiated when the children felt ready. The average of 3 reaches was calculated for the anterior-A, anterolateral-AL, anteromedial-AM, medial-M, posteromedial-PM, posterior-P, posterolateral-PL and lateral-L directions. 5 seconds of rest time was given between reaches. Verbal and tactile prompts were given to the children by the researcher.

Children continued their single leg stance with the dominant leg, reaching as far as possible with the contralateral leg. The children returned to bilateral posture when maintaining balance. If the child could not maintain the single-limb stance, the trial was removed and repeated the testing trial (Robinson\& Gribble,2008a; Robinson\& Gribble,2008b, Olmsted et al. 2002; Plisky, et al. 2006). Besides, the children dominant leg was determined by asking a question "while you shot the ball, which leg do you use?". The measurements were performed with only the dominant leg.

\subsection{Analysis of Data}

Statistical analysis was performed in SPSS software version 23.0. All data were computed as means and standard deviation (SD) and tested for normality using Shapiro-Wilks test. Independent-Samples T test was used to evaluate for the data shown normal distribution. The significance level was set at $\mathrm{p}<0.05$ for all data.

\section{Results}

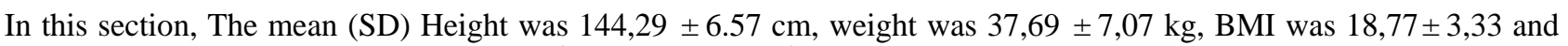
the waist-hip ratio was $0,95 \pm 0,07$ for the $5^{\text {th }}$ grade. For the $7^{\text {th }}$ grade, the mean (SD) Height was $152,94 \pm 6.77 \mathrm{~cm}$, weight was $44,87 \pm 6,55 \mathrm{~kg}$, BMI was $19,19 \pm 2,61$ and the waist-hip ratio was $0,99 \pm 0,14$. Besides a significant difference between the $5^{\text {th }}$ grade and $7^{\text {th }}$ grade was found for the height, weight and waist-hip ratio $(\mathrm{p}<0.05)$ in table 1 .

Table 1. Scores of physical characteristics of children according to class variable

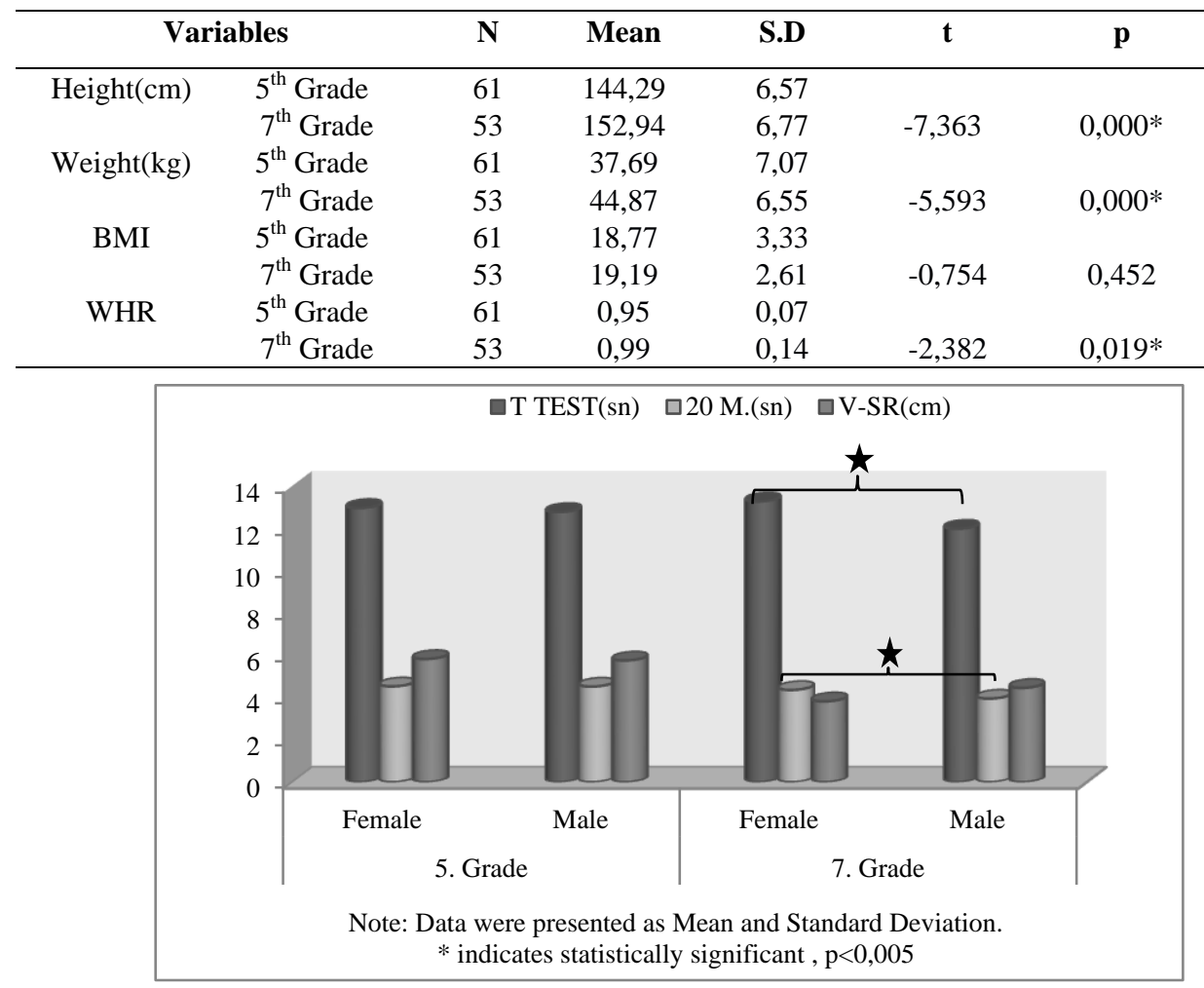

Figure 1. Results of the T-test, $20 \mathrm{~m}$ run and $\mathrm{V}$-sit and reach according to gender 
In Figure 1, a significant difference between the female and male groups was found for the T-Test and $20 \mathrm{~m}$. Sprint test in $7^{\text {th }}$ grade $(\mathrm{p}<0.05)$. There were no significant differences between the female and male groups for T-Test, $20 \mathrm{~m}$. Sprint and V-Sit reach test in $5^{\text {th }}$ grade $(\mathrm{p}>0.05)$.

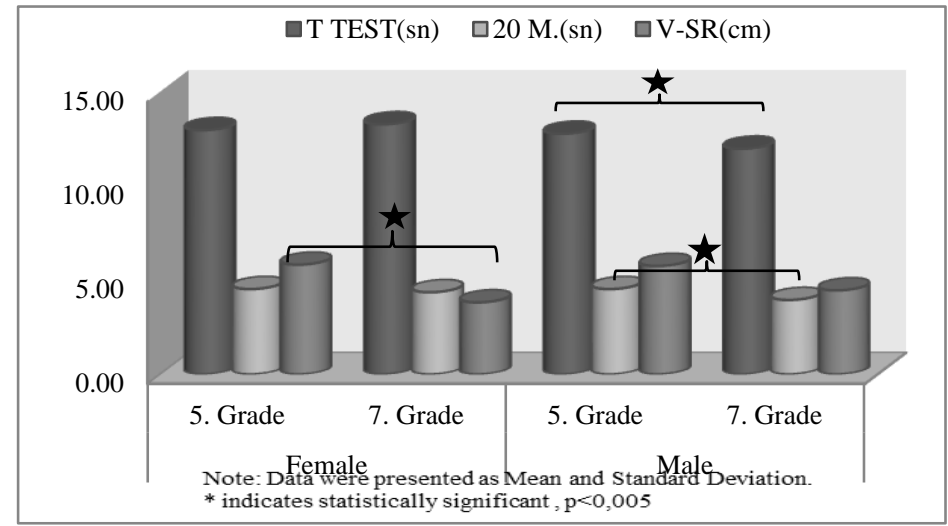

Figure 2. Results of the T-test, $20 \mathrm{~m}$ run and $\mathrm{V}$-sit and reach according to grade

In Figure 2, a significant difference between the $5^{\text {th }}$ grade and $7^{\text {th }}$ grade groups was found for the T-Test and $20 \mathrm{~m}$ Sprint test in male children $(\mathrm{p}<0.05)$. There was a significant difference only in V-Sit reach test results between $5^{\text {th }}$ and $7^{\text {th }}$ grade female students $(\mathrm{p}<0.05)$.

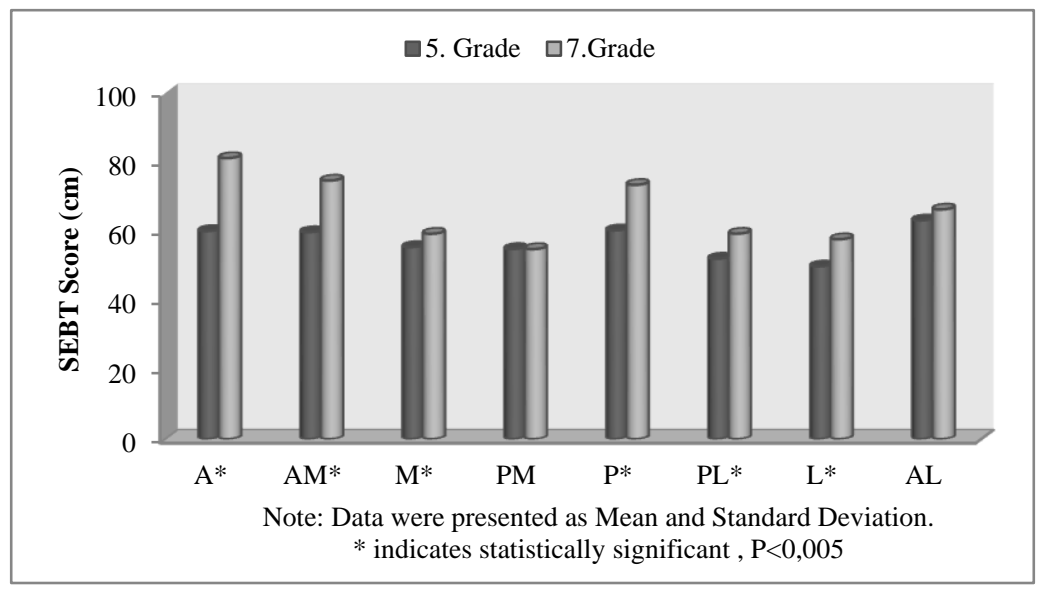

Figure 3. Results of the Star Excursion Balance Test according to grade for the dominant leg

Significant differences were shown between $5^{\text {th }}$ grade and $7^{\text {th }}$ grade for Anterior, Anteromedial, Medial, Posterior, Posterolateral and Lateral directions in Figure $2(\mathrm{p}<0.05)$. However, no significant differences were found between $5^{\text {th }}$ grade and $7^{\text {th }}$ grade for Posteromedial and Anterolateral directions $(\mathrm{p}>0.05)$.

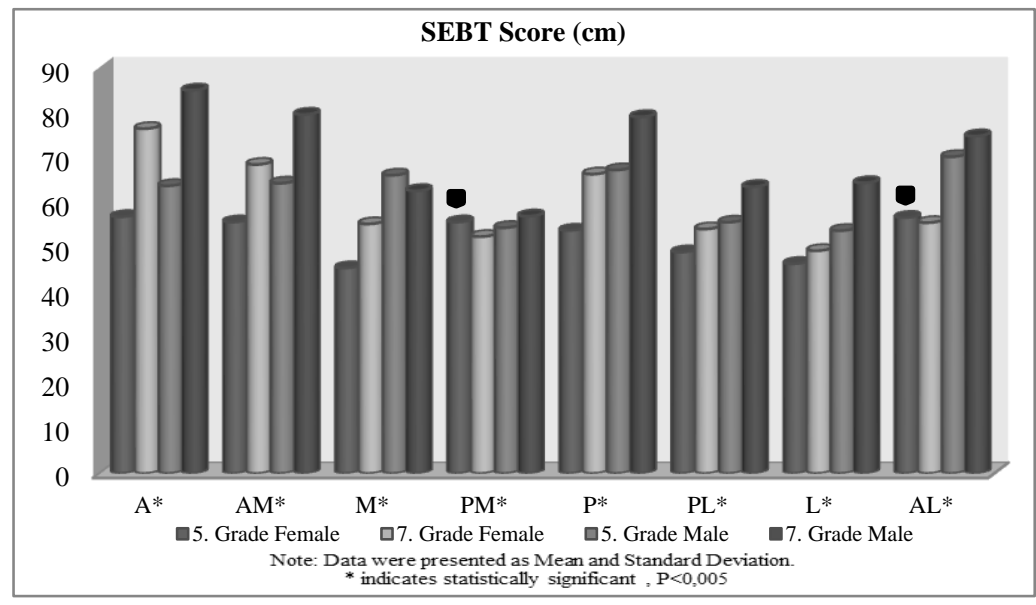

Figure 4. Results of the Star Excursion Balance Test according to grade and gender for dominant leg 
While significant differences were shown between $5^{\text {th }}$ grade and $7^{\text {th }}$ grade for Anterior, Anteromedial, Medial, Posterior, Posterolateral and Lateral directions in female children $(p<0.05)$, significant differences were not found for Posteromedial and Anterolateral directions ( $\mathrm{p}>0.05$ ). Besides Statistical significance was determined for all directions between $5^{\text {th }}$ and 7 th grade male children.

\section{Discussion}

This work was done to examine the development and differences of some components of motor skill competence (eg, dynamic balance, flexibility, speed, and agility) and health-related physical fitness (eg weight, BMI, WHR) in terms of age, grade and gender. When the difference between the two grade was analyzed, there was a significant difference between the groups in height, weight and waist-hip ratio (Table 1). It was thought that the difference was due to the development in children. Because, Weight and body weight are the most useful variables to assess growth and development speed(Physical Activity and Health, 1996). Muratlı (1997) said that the annual elongation rate for males between 9 and 12 years was half of the females and while the elongation of the girls slowed down at age 13, the men started to accelerate.

The results showed that there was no statistically significant difference between $5^{\text {th }}$ grade males and females children in terms of the averages of the agility, $20 \mathrm{~m}$ Sprint and flexibility tests(Figure 1)(p>0.005). It was stated that flexibility was stable between 5 and 8 years in female and male(Branta et al., 1984). It was reported that during the pre-adolescent years, males and females appear to demonstrate similar capacities for agility-related tasks (Eisenmann and Malina 2003). It was found that the agility, speed and flexibility performances were similar of fifth-grade male and girls in this study. But, the agility and sprint test averages were found to be statistically significant between the $7^{\text {th }}$ grade males and females children $(\mathrm{p}<0.005)$ and the male children sprint and agility performance values were determined to be higher than female. Sekulic and colleagues found that men had better agility performance than girls and differences were significant (Sekulic et al., 2013). It was seen that the results were in parallel with this study. While there was no difference in the agility performance and speed of the $7^{\text {th }}$ and $5^{\text {th }}$ grade female children, $5^{\text {th }}$ grade female children had better flexibility performance than $7^{\text {th }}$ grade female(Figure 2) and it was thought to be caused by factors such as heredity and joint structure. Branta stated that for girls, flexibility increased after about 11 years of age and occurs in the adolescence period when the extremity length increases (Branta et al., 1984).

Speed was the most commonly used action as a target and was progressed with the age in female and in male (Haugen et al.,2014; Papaiakovou et al., 2009). In the current study, it was found that $7^{\text {th }}$ male children performed better than $5^{\text {th }}$ male in $20 \mathrm{~m}$ sprint test $(\mathrm{p}<0.005)$ and as the cause, was thought to be influenced by height length and step frequency(Figure 2). Besides, It had been reported that age positively affects sprint speed, and boys of all ages ran faster than girls, especially after childhood (Branda et al. 1984). It is reported that the speed performance increases with age(Eniseler, 2009; Kail and Ferrer, 2007) and height length was a factor affecting speed due to increased step length(Ecker, 1996). Eniseler, (2009) reported that speed performance increased with increasing strength and age and they compared performance values of children in 12-14 age group such as; $20 \mathrm{~m}$ sprint value of 12 years old children is $3.52 \mathrm{sec}, 20 \mathrm{~m}$ sprint value of 13 years old children is $3,44 \mathrm{sec}, 20 \mathrm{~m}$ sprint value of 14 years old children is $20 \mathrm{~m}$ sprint value is $3,26 \mathrm{sec}$.

Sporis et al. (2010) identified that agility was as the ability to maintain and control correct body positions while rapidly changed direction with a series of movements and they said that apart from speed and explosive strength, an improvement of balance should be considered as one of the key features of agility improvement. As shown in figure 1; While $5^{\text {th }}$ grade male and female students had similar agility values, there was a significant difference between $7^{\text {th }}$ grade male and female children in agility performance. In this study was thought that 7. Grade male children had greater muscle mass with growth which allowed them to generate greater force, speed and energy. Pande et al. (2017) found that the female school children had lower running speed and agility performance than men in their study. The results of this study were similar to those of Pande et al. (2017) research. Smajik et al. (2017) stated that the motor abilities of younger school boys and girls differ significantly in terms of: flexibility, agility and explosive strength, while differences in the speed of alternative movements do not exist. Besides, The research done by Obradović and his colleagues supported the results of this study (Obradović et al. 2008).

As shown in figure 4, It was determined that there was a significant difference between the average of the $5^{\text {th }}$ and $7^{\text {th }}$ grade female children for Anterior, Anteromedial, Medial, Posterior, Posterolateral and Lateral directions in SEBT value and $7^{\text {th }}$ grade female children had higher the average of SEBT values. While no significant differences were found between $5^{\text {th }}$ grade and $7^{\text {th }}$ grade female children for Posteromedial and Anterolateral directions, $5^{\text {th }}$ and $7^{\text {th }}$ grade male children had significant differences in SEBT values for all directions. When the morphological characteristics of male and female children aged 11-13 years were considered, it had been found that both male and female children had an effect of the volume of the body in the emergence of all motor skills(Obradović et al. 2008, Krsmanović et al. 2009). 
Riach and Hayes (1987) defended that there may be age-related changes in the balance. They also stated that there were gender differences in balance between the children and that they began adopting balance strategies similar to adults after seven years of age. Hageman et al. (1995) conducted a study to identify age and gender-related changes in postural control measurements. While the results showed that gender was not associated with balance scores, the age was associated with all measures. It was seen that the researches made by the authors support the results of this study. At the end of study, it was thought that if the increase in muscle mass was considered with the advance of age, the dynamic balance could be affected from age and the anthropometric characteristics could be caused changes of the center of gravity. It was observed that there was an increase in agility, speed and dynamic equilibrium performance data especially from the age of 11 in parallel with growth and development. Especially from this period, it was thought that it was possible to develop motor skills and performance parameters with some sports applications and training.

\section{References}

Bompa, T. O. (2003). Training Theory and Methodology, Bağırgan Publication, Ankara.

Branda, C., Haubenstricker, J., \& Seeffeldt, V. (1984). Age changes in motor skills during childhood and adolescence. Exerc Sport Sci Rev., 12, 467-520. https://doi.org/10.1249/00003677-198401000-00015

Clark, J. E. (2005). From the Beginning: A Developmental Perspective on Movement and Mobility. Quest, 57, 37-45. https://doi.org/10.1080/00336297.2005.10491841

Ecker, T. (1996). Basic biomechanics of running. Basic Track \& Field Biomechanics. Mountain View. Tafnews Press, $57-63$.

Eisenmann, J. C., \& Malina, R. M. (2003). Age and sex-associated variation in neuromuscular capacities of adolescent distance runners. J. Sports Sci., 21, 551-557. https://doi.org/10.1080/0264041031000101845

Eniseler, N. (2009). Soccer training in children and teens. ( $1^{\text {th }}$ ed.). TFF FGM Football Training Publications. Istanbul, 51.

Fong, S. M., \& Ng, G. Y. F. (2012). Sensory integration and standing balance in adolescent taekwondo practitioners. Pediatric Exercise Science, 24(1), 142-151. https://doi.org/10.1123/pes.24.1.142

Gallahue, D. L., \& Ozmun, J. C. (2006). Understanding Motor Development” Infants, Children, Adolescents, Adults. ( $6^{\text {th }}$ ed.) McGraw-Hill, New York, NY, USA.

Gallahue, D. L., Ozmun, J. C., \& Goodway, J. (2012). Understanding motor development: Infants, children, adolescents, adults.( $7^{\text {th }}$ ed.). New York: McGraw-Hill.

Haga, M. (2008). The relationship between physical fitness and motor competence in children. Child: Care, Health and Developmen, 34(3), 329-334. https://doi.org/10.1111/j.1365-2214.2008.00814.x

Hageman, P., Leibowitz, J., \& Blanke, D. (1995). Age and gender effects on postural control measures. Arch. Phys. Med. Rehabil., 76, 961-965. https://doi.org/10.1016/S0003-9993(95)80075-1

Hands, B., Larkin, D., Parker, H., Straker, L., \& Perry, M. (2009). The relationship among physical activity, motor competence and health-related fitness in 14-year-old adolescents. Scand. J. Med. Sci. Sports, 19(5), 655-663. https://doi.org/10.1111/j.1600-0838.2008.00847.x

Haugen, T., Tonnessen, E., Hisdal, J., \& Seiler, S. (2014). The role and development of sprinting speed in soccer. Int J Sports Physiol Perform, 9(3), 432-441. https://doi.org/10.1123/ijspp.2013-0121

Henderson, S. E., \& Sugden, D. (1992). The Movement Assessment Battery for Children. Kent, United Kingdom: The Psychological Corporation.

Heyward, V. H. (2006). Advanced Fitnessassessment and ExercisePrescription (5nd ed.). USA, HumanKinetics.

Hui, S. S. C., \& Yuen, P. Y. (2000). Validity of the modified back-server sit and reach test: a comparison with other protocols. Medicine and Science in Sport and Exercise, 32(9), 1655-1659. https://doi.org/10.1097/00005768-200009000-00021

Jordan, J. B., Korgaokar, A., Farley, R. S., Coons, J. M., \& Caputo, J. L. (2014). Caffeine supplementation and reactive agility in elite youth soccer players. Pediatric Exercise Science, 26(2), 168-176. https://doi.org/10.1123/pes.2013-0134

Kail, R. V., \& Ferrer, E. (2007). Processing speed in childhood and adolescence: Longitudinal models for examining developmental change. Child Dev., 78(6), 1760-1770. https://doi.org/10.1111/j.1467-8624.2007.01088.x

Kinzey, S. J., \& Armstrong, C. W. (1998). The reliability of the star-excursion test in assessing dynamic balance. Journal of Orthopaedic \& Sports Physical Therapy, 27(5), 356-360. https://doi.org/10.2519/jospt.1998.27.5.356 
Kocak, M., Akkoyunlu, Y., \& Taskin, H. (2005). Influence on the flexibility of massages of 16 to 18 age group footballers. Spormetre Journal of Physical Education and Sport Sciences, 3(3), 105-109.

Krsmanović, B., Batez, M., \& Krsmanović, T. (2009). The influence of anthropometric characteristics and motor abilities of female pupils on motor efficiency. Glasnik antropološkog društva Srbije, 44, 401-410.

Miller, M. G., Herniman, J. J., Ricard, M. D., Cheatham, C. C., \& Michael, T. J. (2006). The effects of a 6-week plyometric training program on agility. J Sports Sci Med., 5(3), 459-465.

Muratlı S. (1997). Child and Sports Under the Light of Training Science. Bağırgan Printing. Ankara/Turkey, 8-15-185.

Obradović, J., Cvetković, M., \& Krneta, Ž. (2008). The differences in motor abilities of children younger school age in relation to gender. Sport Mont. ,15, 16, 17./VI, 527- 533.

Olmsted, L. C., Carcia, C. R., Hertel, J., \& Shultz, S. J. (2002). Efficacy of the star excursion balance tests in detecting reach deficits in subjects with chronic ankle instability. Journal of Athletic Training, 37(4), 501-506.

Özer, K. (2006). Physical fitness. Nobel Publication Distribution, Ankara.

Pande, A., Rathi, M., Dhote, S., Palekar, T., Dhige, A., \& Yengde, P. (2017). Running Speed and Agility according to Bruininks Oseretsky Test of Motor Proficiency. Int. J. Med. Health Sci., 6-2.

Papaiakovou, G., Giannakos, A., Michailidis, C., Patikas, D., Bassa, E., Kalopisis, V., \& Ninkolaos, A. (2009). The effect of chronological age and gender on the development of sprint performance during childhood and puberty. Journal of Strength and Conditioning Research, 23(9), 2568-2573. https://doi.org/10.1519/JSC.0b013e3181c0d8ec

Pauole, K., Madole, K., Garhammer, J., Lacourse, M., \& Rozenek, R. (2000). Reliability and validity of the T-test a measure of agility, leg power, and leg speed in college-aged men and women. J. Strength Conditioning Research, $14,443-450$.

Physical Activity and Health (1996). A Report of the Surgeon General, At-A-Glance. U.S. Department of Health and Human Services, Centers for Disease Control and Prevention. National Center for Chronic Disease Prevention and Health Promotion,The President's Council on Physical Fitness and Sports. Retrieved from https://www.cdc.gov/nccdphp/sgr/pdf/sgraag.pdf .10.05.2018.

Piek, J. P., Baynam, G. B., \& Barrett, N. C. (2006). The relationship between fine and gross motor ability, self-perceptions and self-worth in children and adolescents. Hum. Mov. Sci., 25(1), 65-75. https://doi.org/10.1016/j.humov.2005.10.011

Plisky, P. J., Rauh, M. J., Kaminski, T. W., \& Underwood, F. B. (2006). Star Excursion Balance Test as a predictor of lower extremity injury in high school basketball players. J. Orthop. Sports Phys. Ther., 36(12), 911-919. https://doi.org/10.2519/jospt.2006.2244

Reilly, T., Bangsbo, J., \& Franks, A. (2000). Anthropometric and physiological predispositions for elite soccer. J. Sport Sci., 18, 669-683. https://doi.org/10.1080/02640410050120050

Riach, C., \& Hayes, K. (1987). Maturation of postural sway in young children. Developmental Medicine and Child Neurology, 29, 650-658. https://doi.org/10.1111/j.1469-8749.1987.tb08507.x

Robinson, R. H., \& Gribble, P. A. (2008a). Support for a reduction in the number of trials needed for the star excursion balance test. Arch Phys Med Rehabil., 89, 364-370. http://dx.doi.org/10.1016/j. apmr.2007.08.139.

Robinson, R. H., \& Gribble, P. A. (2008b). Kinematic predictors of performance on the Star Excursion Balance Test. J Sport Rehabil., 17(4), 347-57. https://doi.org/10.1123/jsr.17.4.347

Ross, A., Leverit, M., \& Riek, S. (2001). Neural influences on sprint running. Training adaptations and acute responses. Sports Med., 31,409-425. https://doi.org/10.2165/00007256-200131060-00002

Santiago, A., Granados, C., Quintela, K., \& Yanci, J. (2015). Differences in the acceleration, change of direction and jumping capacity between different ages soccer players. Cultura Ciencia Deporte., 10(29), 135-143. https://doi.org/10.12800/ccd.v10i29.551

Sekulic, D., Spasic, M., Mirkov, D., Cavar, M., \& Sattler, T. (2013). Gender-specific influences of balance, speed, and power on agility performance. J. Strength Cond. Res., 27(3), 802-811.

https://doi.org/10.1519/JSC.0b013e31825c2cb0

Sheppard, J. M., \& Young, W. B. (2006). Agility literature review: Classifications, training and testing. J. Sports Sci. ,24(9), 919-932. https://doi.org/10.1080/02640410500457109 
Smajik, M., Cokorilo, N., Petrovic, V., Stajer, V., Micic, R., \& Ilic, M. (2017). Gender-related differences in motor abilities of children in the fencing school. EQOL Journal, 9(1),31-35.

Sporis, G., Jukic, I., Milanovic, L., \& Vucetic, V. (2010). Reliability and factorial validity of agility tests for soccer players. J Strength Cond Res., 24, 679-686. https://doi.org/10.1519/JSC.0b013e3181c4d324

Stepinski, M., Zwierko, T., Florkiewicz, B., \& Debicka, J. (2003). The level of chosen motor abilities of 13 years old soccer players. Journal of Human Kinetics, 9, 99-106.

Vanttinen, T., Blomqvist, M., Nyman, K., \& Ha" kkinen, K. (2011). Changes in body composition, hormonal status, and physical fitness in 11-, 13-, and 15-year-old Finnish regional youth soccer players during a two-year follow up. $J$ Strength Cond Res., 25, 3342- 3351. https://doi.org/10.1519/JSC.0b013e318236d0c2

Westcott, S. L., Lowes, L. P., \& Richardson, P. K. (1997). Evaluation of postural stability in children: current theories and assessment tools. Phys Ther., 77(6), 629-45. https://doi.org/10.1093/ptj/77.6.629

William, B. S., Carl, L. S., Ronald, E. S., Jack, H. W., \& Michael, P. (1989). Strength, flexibility, and maturity in adolescent athletes. Am J Dis Child, 143(5), 560-563. https://doi.org/10.1001/archpedi.1989.02150170058022

Zorba, E. (2001). Physical Fitness. Muğla: Gazi Bookstore.

\section{Copyrights}

Copyright for this article is retained by the author(s), with first publication rights granted to the journal.

This is an open-access article distributed under the terms and conditions of the Creative Commons Attribution license which permits unrestricted use, distribution, and reproduction in any medium, provided the original work is properly cited. 